\title{
Effect of cell-plating density on the steroidogenic activity of human cumulus cells
}

\author{
S. Bar-Ami ${ }^{1,2}$ and C. Khoury ${ }^{1}$ \\ ${ }^{1}$ The Bruce Rappaport Faculty of Medicine, Technion-Israel Institute of Technology, PO Box 9649, \\ 31096 Haifa, Israel; and ${ }^{2}$ Department of Obstetrics and Gynecology, Rambam Medical Center, \\ PO Box 9602, 31096 Haifa, Israel
}

\begin{abstract}
Expansion of the cumulus mass results in dilution of cumulus cells in accumulated hyaluronic acid. This process is associated with an increase in progesterone secretion. The present study was carried out to evaluate the relationship between these two processes in vitro. Dilution of human cumulus cells was attempted by changing the cell-plating density of cumulus cells in culture. Concurrent with an increase in cell-plating density from $0.25 \times 10^{4}$ to $8 \times 10^{4}$, progesterone secretion increased by 10.5 times $(P<0.001), 9$ times $(P<0.001)$, and 5.9 times $(P<0.001)$, and oestradiol secretion increased by 1.4 times $(P<0.001)$, 1.1 times $(P>0.05)$, and 2.6 times $(P<0.005)$ during days $0-3,3-5$, and $5-7$ of culture, respectively. However, when steroid secretion was expressed in terms of ng per number of cells, the increase in cell-plating density from $0.25 \times 10^{4}$ to $8 \times 10^{4}$ coincided with a decrease in progesterone secretion of 3 times $(P<0.001), 3.5$ times $(P<0.001)$, and 5.4 times $(P<0.005)$, and oestradiol secretion decreased by 23 times $(P<0.001), 30$ times $(P<0.001)$, and 12.5 times $(P<0.001)$ during days $0-3,3-5$, and $5-7$ of culture, respectively. The progesterone:oestradiol ratio increased gradually with the increase in cell-plating density. However, at the higher range of cell-plating density the progesterone: oestradiol ratio decreased with extension of the culture period. Addition of human FSH $(\mathrm{hFSH})$ or hCG increased progesterone secretion when the cumulus cells were plated at $2 \times 10^{4}$, but in most cases not at $0.25 \times 10^{4}$ or $8 \times 10^{4}$ cells per dish. However, both hFSH and hCG decreased oestradiol secretion at $2 \times 10^{4}$ cells per dish. In the presence of gonadotrophins, an increase in cell contact and cytoplasmic processes during days $0-3$ and 3-5 was noted. This study indicates that secretion of progesterone and oestradiol per number of cells is significantly increased with a decrease in cell-plating density. Furthermore, addition of gonadotrophin increased progesterone and decreased oestradiol secretion at the middle range of cell-plating density.
\end{abstract}

\section{Introduction}

In the periovulatory phase, after the gonadotrophin surge, cumulus cells undergo dramatic changes in morphology and biochemistry. Hyaluronic acid accumulates between the cumulus cells, and gap junctional elements disintegrate (Sotelo and Porter, 1959; Dekel and Kraicer, 1978; Eppig, 1987). Thus, the syncytial structure, which is typical of the cumulus mass and mural granulosa cells and which allows the transportation of molecules between the cumulus cells and the oocyte, is no longer present (Moor and Cran, 1980; Racowsky and Satterlie, 1985). These processes are part of the events leading to cumulus mucification and expansion (Chen et al., 1990). Ultimately, the ovulated egg is accompanied by the mucified cumulus mass, which remains with it in the oviduct for several days (Pereda et al., 1989).

In granulosa cells, an increase either in the enzymes cholesterol side-chain-cleavage, cytochrome P-450 ( $\mathrm{P}-45 \mathrm{O}_{\text {scc }}$ ),
$3 \beta$-hydroxysteroid dehydrogenase and aromatase cytochrome $\mathrm{P}-450$, or in the secretion of progesterone by follicular cells is observed following the LH surge in the newly formed corpus luteum (Sano et al., 1981; Sasano et al., 1989; Doody et al., 1990). In cumulus cells, the increase in P-450 ${ }_{\text {scc }}$ activity occurs only in cumulus-oocyte complexes in which the oocyte has undergone germinal vesicle breakdown (Goldschmit et al., 1989). Similarly, the induction of cumulus mass expansion by FSH occurs only in the presence of a meiotically active oocyte (Vanderhyden et al., 1990). The oocyte is necessary for the synthesis and accumulation of hyaluronic acid in the cumulus mass (Salustri et al., 1990).

Taken together, these studies have evaluated altered steroidogenic activity in cumulus cells in relation to a possible interaction with the oocyte. However, cause-and-effect relationships within the cumulus oophorus have not been extensively studied.

The dramatic expansion in the volume of the cumulus oophorus results in a decrease in density of cumulus cells. The 
question of whether cell density has a role in the altered progesterone secretion in cumulus cells has not been studied. A decrease in the plating density of cumulus cells in culture was therefore used to mimic, at least in part, the dilution of cumulus cells within the hyaluronic mass that occurs in vivo after the endogenous $\mathrm{FSH} / \mathrm{LH}$ surge or exogenous hCG administration.

\section{Materials and Methods}

Cumulus cells were collected from 27 women who were admitted to the IVF-embryo transfer programme because spermatozoa of their husbands were incapable of penetrating the oocyte. In these circumstances, only naked oocytes were used for IVF and cumulus cells were discarded since they have no clinical function. Permission was obtained to use these cells for the present study.

Multiple follicular growth was stimulated in the patients by daily treatment with 150 iu human $\mathrm{FSH}$ (hFSH; Metrodin: Teva, Petah Tiqva) combined with 150 iu human menopausal gonadotrophin (Pergonal: Teva), beginning on day 2 or 3 of the menstrual cycle and continuing until days 9-11.

In some patients, stimulation by gonadotrophin was preceded by, or associated with, treatment with GnRH, which was initiated in the early follicular phase and administered either as a single injection i.m. of $3.2 \mathrm{mg} \mathrm{GnRH}$ analogue (D-Trp6$\mathrm{LHRH}$, Ferring, Malmö), which results in a tonic release of $0.1 \mathrm{mg} \mathrm{GnRH}$ day $^{-1}$ or as the GnRH analogue Buserelin (Hoechst, Frankfurt-am-Main) given via nasal inhalation (dose: approximately $800 \mu \mathrm{g} \mathrm{day}^{-1}$ ) and continuing until the day of $\mathrm{hCG}$ administration. In women receiving $\mathrm{GnRH}$ treatment, the gonadotrophin stimulation lasted for about 12 days. In all instances, ovulation was induced by a single injection of 10000 U hCG i.m. (Chorigon: Teva) after two or more follicles had reached $16-17 \mathrm{~mm}$ in diameter.

\section{Culture of human cumulus cells}

Cumulus-oocyte complexes were aspirated $36 \mathrm{~h}$ after administration of hCG. Each complex was carefully washed in $1.5 \mathrm{ml}$ culture medium (see below) to remove the residual blood and other follicular cells. Three cumulus-oocyte complexes were placed in each organ culture dish (Falcon, Oxnard, CA) filled with $1.5 \mathrm{ml}$ culture medium consisting of synthetic human tubal fluid (HTF; Irvine Scientific, Santa Ana, CA) supplemented with $10 \%$ human cord serum. The human cord serum was prepared as described by Bar-Ami et al. (1989). After incubation for 4-6h, these complexes were washed again in $1.5 \mathrm{ml}$ culture medium and placed into HTF medium supplemented with $\mathrm{I} \mathrm{mg}$ bovine testis hyaluronidase $\mathrm{ml}^{-1}$ (Sigma Chemical Co., St Louis, MO). Cumulus cells, that is, the cells contained in the mucified mass attached to the oocyte were removed (by repeated pipetting for 1-2 min at room temperature with a Pasteur pipette) only when denuded oocytes were needed to achieve fertilization by the micromanipulation method as described by Cohen et al. (1992). The cumulus cells were centrifuged at $400 \mathrm{~g}$ for $10 \mathrm{~min}$ at room temperature. The cell pellet was suspended in Ham's F-10 culture medium (see below). Centrifugation was repeated and the cells resuspended in $2 \mathrm{ml}$ of fresh Ham's F-10 culture medium. A known number of intact, viable cells were plated in $0.5 \mathrm{ml}$ of Ham's F-10 culture medium in organ culture dishes (Falcon). Cell viability was assessed using trypan blue (Gibco, Grand Island, New York), diluted to a final concentration of $0.04 \%(w: v)$ for the dye-exclusion test.

Cumulus cells were cultured in medium consisting of $9.8 \mathrm{~g}$ Ham's F-10 powder $1^{-1}$, buffered with $2.1 \mathrm{~g}$ sodium bicarbonate $I^{-1}$ and $10 \mathrm{mmol}$ Hepes $1^{-1}$ and enriched with $1 \mathrm{mmol}$ glutamine $\mathrm{l}^{-1}, 50$ iu streptomycin $\mathrm{ml}^{-1}: 50 \mu \mathrm{g}$ penicillin $\mathrm{ml}^{-1}$ (all purchased from Gibco), and 5\% (v:v) human cord serum. Sometimes, the Ham's F-10 culture medium was supplemented either with $40 \mathrm{ng} \mathrm{hCG} \mathrm{ml}^{-1}$ (CR 121; kindly provided by the Center for Population Research of the National Institute of Child Health and Human Development, National Institutes

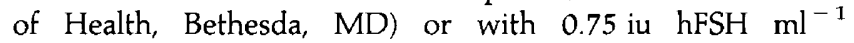
(Metrodin: Teva). The cumulus cells were inoculated at 0.25 , $0.5,1,2,4$, or $8 \times 10^{4}$ cells per dish. Cumulus cells were cultured for 7 days in a humidified $5 \% \mathrm{CO}_{2}: 95 \%$ air incubator at $37^{\circ} \mathrm{C}$, with a change in medium after 3 and 5 days in culture. The three phases of the culture period were designated days $0-3$, days $3-5$ and days $5-7$ of culture. Medium was collected on days 3,5 , and 7 of culture and stored at $-20^{\circ} \mathrm{C}$ until steroid radioimmunoassay.

\section{Steroid radioimmunoassay}

The radioimmunoassay was carried out, as described by Bar-Ami et al. (1989), on unextracted samples. Culture media

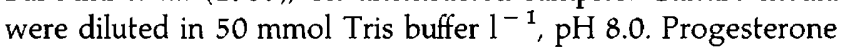
and oestradiol concentrations were measured using high specific activity tritiated hormones (progesterone, labelled at loci 1, 2, 6, 7, 16, and 17, and oestradiol, labelled at loci 2, 4, 6, 7, 16, and 17: Amersham Radiochemical Centre, Amersham, Bucks) and rabbit anti-progesterone or anti-oestradiol (BioMakor, Rehovot), respectively. The contributions of human cord serum oestradiol and progesterone to the culture media were in the range of $3-8 \%$ and $1.5-2 \%$ of the total measured steroid concentration, respectively. These values were, therefore, subtracted from the corresponding progesterone and oestradiol values measured in the cumulus cell conditioned media to give the net steroid output.

\section{Statistical analysis}

Results are expressed as means \pm SEM of all data collected from a total of seven experiments, each carried out in triplicate. Each experiment included cumulus cells pooled from two to four women. Data were subjected to one-way ANOVA, followed by Student's $t$ test for individual comparison between means.

\section{Results}

\section{Basal steroid production by cumulus cells}

Cumulus cells were collected from 15 women. Cells were plated at increasing cell-plating densities from $0.25 \times 10^{4}$ 

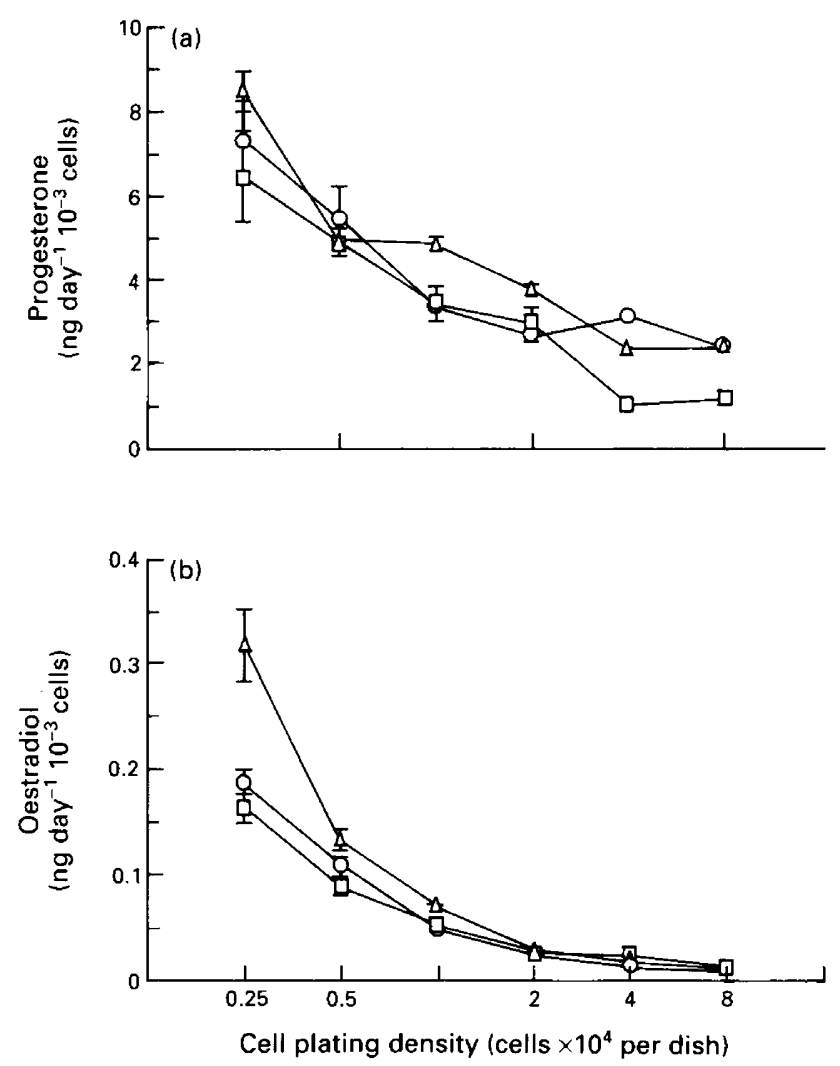

Fig. 1. Effect of an increase in cell-plating density on (a) progesterone and (b) oestradiol secretion $10^{-3}$ human cumulus cells during days $(0)$ $0-3,(\triangle)$ 3-5, and () 5-7 of culture. Each datum point represents the mean steroid concentration per dish ( \pm SEM) of duplicate culture wells of six experiments and data were subjected to one-way ANOVA. For (a) progesterone: during days $0-3, F=15$ and $P<0.001$; during days $3-5, F=98$ and $P<0.001$; during days $5-7, F=15$ and $P<0.001$. For (b) oestradiol: during days $0-3, F=95$ and $P<0.001$; during days $3-5, F=62$ and $P<0.001$; during days $5-7, F=79$ and $P<0.001$.

to $8 \times 10^{4}$ cells per dish. Concurrent with the increase in cell-plating density was a dramatic increase in progesterone secretion, of 10.5 times $(P<0.001)$, 9 times $(P<0.001)$, and 5.9 times $(P<0.001)$ during days $0-3,3-5$, and 5-7, respectively (data not shown). The increase in cell-plating density also resulted in an increase in oestradiol secretion of 1.4 times $(P<0.001)$ and 2.6 times $(P<0.005)$ during days $0-3$ and $5-7$, respectively (data not shown).

Steroid output decreased per number of cells with the increase in cell-plating density (Fig. 1). Progesterone and oestradiol secretion decreased by three times $(P<0.001)$ and 23 times $(P<0.001)$, respectively, during days $0-3$; by 3.5 times $(P<0.001)$ and 30 times $(P<0.001)$, respectively, during days $3-5$; and 5.4 times $(P<0.005)$ and 12.5 times $(P<0.001)$, respectively, during days 5-7 of culture.

The progesterone:oestradiol ratio, which partially indicates the degree of follicular cell luteinization, significantly increased with the increase in cell-plating density (Table 1 ) by 6.9-fold $(P<0.001), 8.8$-fold $(P<0.001)$, and 2.5 -fold $(P<0.005)$ during days $0-3,3-5$, and $5-7$, respectively. Extension of the culture period resulted in a decrease in the progesterone:oestradiol
Table 1. Change in progesterone:oestradiol ratio in human cumulus cells in relation to cell-plating density

\begin{tabular}{lccc}
\hline $\begin{array}{l}\text { Number } \\
\text { of human } \\
\text { cumulus cells } \\
\text { inoculated } \\
\text { per dish } \\
\left(\times 10^{4}\right)\end{array}$ & \multicolumn{3}{c}{ Progesterone:oestradiol ratio } \\
\cline { 2 - 4 } & \multicolumn{3}{c}{$\begin{array}{c}\text { Culture period (days) } \\
3-5\end{array}$} \\
\hline & $0-3$ & $5-7$ \\
0.25 & $40 \pm 4^{\mathrm{a}}$ & $29 \pm 3^{\mathrm{a}}$ & $37 \pm 11^{\mathrm{a}}$ \\
0.5 & $50 \pm 11^{\mathrm{a}, \mathrm{b}}$ & $45 \pm 6^{\mathrm{b}}$ & $40 \pm 4^{\mathrm{a}}$ \\
1.0 & $68 \pm 8^{\mathrm{b}}$ & $79 \pm 11^{\mathrm{c}}$ & $47 \pm 1^{\mathrm{a}}$ \\
2.0 & $116 \pm 13^{\mathrm{c}}$ & $147 \pm 27^{\mathrm{d}}$ & $54 \pm 4^{* \mathrm{a}}$ \\
4.0 & $313 \pm 70^{\mathrm{d}}$ & $187 \pm 33^{\mathrm{d}}$ & $45 \pm 8^{* \mathrm{a}}$ \\
8.0 & $273 \pm 38^{\mathrm{d}}$ & $252 \pm 48^{\mathrm{d}}$ & $94 \pm 11^{* \mathrm{~b}}$
\end{tabular}

Values are means \pm SEM.

${ }^{*} P<0.005$ compared with the progesterone:oestradiol ratio at the same cell-plating density on days $0-3$ and days 3-5 of culture.

For comparison between different cell-plating densities, values with different superscripts are significantly different $(P<0.05)$.

ratio in cumulus cells inoculated at $\geq 2 \times 10^{4}$ cells per dish (Table 1).

\section{Effect of $h F S H$ and $h C G$ on progesterone and oestradiol secretion}

Cumulus cells were collected from 12 women. The effect of hFSH and hCG on progesterone (Fig. 2) and oestradiol (Fig. 3) secretion was studied at increasing cell-plating densities. At $0.25 \times 10^{4}$ cells per dish, there was a significant increase $(P<0.05)$ in progesterone secretion in the hCG-treated cells during days $0-3$. However, neither hFSH nor hCG significantly altered progesterone or oestradiol secretion during the remaining culture period. At $2 \times 10^{4}$ cells per dish, hFSH and hCG increased progesterone secretion 1.6-fold $(P<0.005)$ and 1.5fold $(P<0.005)$, respectively, during days $0-3 ; 1.9$-fold $(P<0.02)$ and 1.7 -fold $(P<0.01)$, respectively, during days $3-5$; and 2.4-fold $(P<0.005)$ and 1.7 -fold $(P<0.02)$, respectively, during days $5-7$. At $2 \times 10^{4}$ cells per dish, hFSH and hCG decreased oestradiol secretion 1.3-fold $(P>0.05)$ and 1.6-fold $(P<0.05)$, respectively, during days $0-3$ and 1.2-fold $(P>0.05)$ and 1.7 -fold $(P<0.05)$, respectively, during days 3-5. Neither hFSH nor hCG altered oestradiol secretion during days 5-7. At $8 \times 10^{4}$ cells per dish, neither hFSH nor hCG caused a significant change in the secretion of progesterone or oestradiol by cumulus cells during the first 5 days of culture $(P>0.05)$. However, during days $5-7$ of culture, there was a significant increase $(P<0.05)$ in progesterone secretion in the hCG- but not in the FSH-treated cells.

Gonadotrophin treatment increased the progesterone: oestradiol ratio in cumulus cells plated at $2 \times 10^{4}$ cells per dish throughout the 7 days of culture (Table 2). At $8 \times 10^{4}$ cells per dish, the gonadotrophins significantly increased the progesterone:oestradiol ratio on days $0-3$, but not during days 5-7. Neither gonadotrophin caused significant increases in the progesterone:oestradiol ratio in cumulus cells plated at $0.25 \times 10^{4}$ cells per dish. 


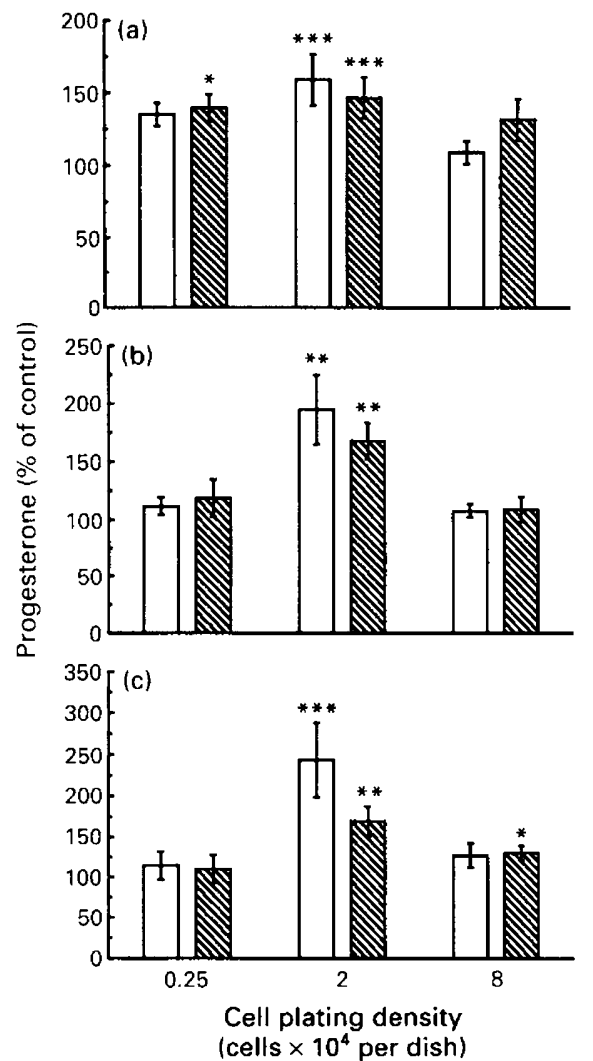

Fig. 2. Effect of $(\square)$ human FSH (hFSH, $0.75 \mathrm{iu} \mathrm{ml}^{-1}$ ) and (\$) hCG $\left(40 \mathrm{ng} \mathrm{ml}^{-1}\right)$ on progesterone secretion from human cumulus cells at increasing cell-plating densities during days (a) $0-3$, (b) 3-5, and (c) 5-7 of culture. Cumulus cells were collected from 12 women. Data were normalized to the corresponding control (taken as 100\%) and were subjected to one-way ANOVA for each gonadotrophin. Each value represents the mean $\pm \mathrm{SEM}$ of six experiments. (a) In $\mathrm{hFSH}$ treated cells, $F=36$ and $P<0.001$; in hCG-treated cells, $F=3.9$ and $P<0.01$. (b) In hFSH-treated cells, $F=12.5$ and $P<0.001$; in hCGtreated cells, $F=6$ and $P<0.001$. (c) In hFSH-treated cells, $F=9$ and $P<0.001$; in hCG-treated cells, $F=4$ and $P<0.001$. Significant differences between a particular experimental group and the corresponding control $(100 \% \pm \mathrm{SEM}$; not shown on the figure) are indicated ${ }^{*} P<0.05,{ }^{*} P<0.02, * * * P<0.005$.

\section{Effect of hFSH and hCG on the morphology of cumulus cells}

Within 3 days of culture, the cumulus cells had completed full attachment to the plastic substratum in basal medium and in the gonadotrophin-supplemented medium. Under basal conditions, cells were not in contact with one another, the cytoplasm was less granular, and they had started to acquire a fusiform morphology (Fig. 4). This process became more marked with time in culture (data not shown). With hFSH treatment, the cumulus cells produced colonies of 10-20 cells maintained in epithelial form with cytoplasmic processes connecting many of the cells (Fig. 4b). With hCG treatment, cumulus cells produced colonies similar to those receiving $\mathrm{hFSH}$ treatment; the cells preserved their epithelial morphology, but acquired more height and appeared more round (Fig. 4c). The cumulus cells had cell to cell contact via abundant cytoplasmic processes, which could be longer than $100 \mu \mathrm{m}$. With the
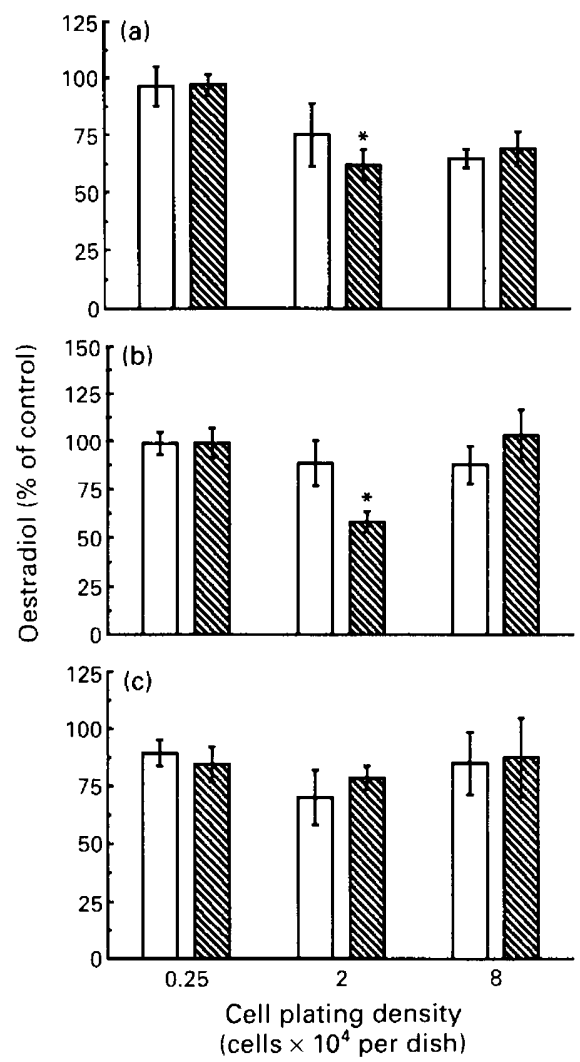

Fig. 3. Effect of ( $\square$ ) human FSH (hFSH, $0.75 \mathrm{iu} \mathrm{ml}^{-1}$ ) and (因) hCG (40 $\mathrm{ng} \mathrm{ml}^{-1}$ ) on oestradiol secretion in human cumulus cells cultured at increasing cell-plating densities during days (a) $0-3$ (b) 3-5 and (c) 5-7 of culture. Data were subjected to one-way ANOVA for each gondotrophin. (a) In hFSH-treated cells, $F=2.5$ and $P>0.05$; in hCG-treated cells, $F=4.5$ and $P<0.05$. (b) In hFSH-treated cells, $F=0.3$ and $P>0.05$; in hCG-treated cells, $F=3$ and $P<0.05$. (c) In hFSH-treated cells, $F=1.4$ and $P>0.05$; in hCG-treated cells, $F=0.4$ and $P>0.05$. Each bar represents the mean \pm SEM of six experiments. Data were normalized to the corresponding control (taken as $100 \%$ ). Significant differences between a particular experimental group and the corresponding control are indicated as $* P<0.05$.

extension of the culture period, cumulus cells became flatter and grainier after gonadotrophin treatment but still preserved their epithelial form and cytoplasmic processes (data not shown).

\section{Discussion}

The study reported here demonstrates the importance of cell-plating density on the steroidogenic activity of cumulus cells. Our data indicate that the secretion of progesterone and oestradiol per number of cells was greater at low cell-plating densities $\left(0.25 \times 10^{4}\right.$ to $\left.1 \times 10^{4}\right)$ than with cumulus cells cultured at high cell-plating densities $\left(4 \times 10^{4}\right.$ or $\left.8 \times 10^{4}\right)$ throughout the 7 days of culture. In addition, increased time in culture was associated with a significant decrease in progesterone secretion and thus, a decrease in the progesterone: oestradiol ratio. However, treatment of cumulus cells at a plating density of $2 \times 10^{4}$ cells per dish, with gonadotrophins 
Table 2. Changes in progesterone:oestradiol ratio in human cumulus cells by human FSH (hFSH) and hCG at increasing cell-plating densities

\begin{tabular}{|c|c|c|c|}
\hline \multirow{3}{*}{$\begin{array}{l}\text { Number of } \\
\text { cumulus cells } \\
\text { inoculated } \\
\text { per dish } \\
\left(\times 10^{4}\right)\end{array}$} & \multirow{3}{*}{$\begin{array}{c}\text { Treatment } \\
\text { in vivo }\end{array}$} & \multicolumn{2}{|c|}{ Progesterone:oestradiol ratio } \\
\hline & & \multicolumn{2}{|c|}{ Culture period (days) } \\
\hline & & $0-3$ & $5-7$ \\
\hline 0.25 & Control & $52 \pm 8$ & $68 \pm 11$ \\
\hline 0.25 & hFSH & $59 \pm 10$ & $78 \pm 9$ \\
\hline 0.25 & hCG & $73 \pm 11$ & $87 \pm 10$ \\
\hline 2.0 & Control & $248 \pm 42$ & $135 \pm 21$ \\
\hline 2.0 & hFSH & $520 \pm 34^{* * *}$ & $492 \pm 45^{* * *}$ \\
\hline 2.0 & hCG & $580 \pm 31^{* * *}$ & $300 \pm 43^{* *}$ \\
\hline 8.0 & Control & $612 \pm 30$ & $552 \pm 107$ \\
\hline 8.0 & hFSH & $1018 \pm 91 * * *$ & $779 \pm 221$ \\
\hline 8.0 & hCG & $946 \pm 121^{*}$ & $860 \pm 241$ \\
\hline
\end{tabular}

Values are means $\pm \mathrm{SEM}$

${ }^{a}$ Control values of progesterone:oestradiol ratio differ from the corresponding values in Table $I$ probably because cumulus cells were collected from a different group of women.

${ }^{*} P<0.05,{ }^{* *} P<0.01,{ }^{* * *} P<0.005$, compared with cumulus cells cultured in medium alone at the same cell-plating density.

resulted in an increase in progesterone and a decrease in oestradiol secretion, reversing the change in the pattern of cumulus cell steroidogenesis that resulted from extension of the culture period. The effect of gonadotrophins was diminished by decreasing or increasing the cell-plating density to $0.25 \times 10^{4}$ or $8 \times 10^{4}$ cells per dish, respectively.

In contrast, in human granulosa-lutein cell cultures an increase in progesterone and a decrease in oestradiol secretion was seen with extension of the culture period (Bar-Ami and Gitay-Goren, 1993). Furthermore, the stimulatory effect of gonadotrophins on progesterone secretion was observed in granulosa-lutein cells cultured at very high cell-plating densities (Bar-Ami and Gitay-Goren, 1993). Thus, these differences between cumulus cells and granulosa-lutein cells are evidence that cumulus cells are a unique cell population among the various follicular cell types.

After the endogenous LH surge or the exogenous administration of LH or hCG, the steroidogenic pathway of follicular cells is altered from oestrogen to progestin production. This involves an increase in the activity of cholesterol P- $450_{\text {scc }}$ (Rodgers et al., 1986; Sasano et al., 1989) and a reduction in the activities of $17 \alpha$-hydroxylase:C-17-C-20 lyase (Sano et al., 1981; Suzuki and Tamaoki, 1983; Johnson, 1988). Luteinized granulosa cells and luteal cells therefore secrete relatively large amounts of progesterone and small amounts of oestrogen. Similar changes in the concentrations of these steroids have been detected in follicular fluid aspirated during IVF-embryo transfer (Carson et al., 1982), in peripheral serum following hCG administration (Yovich et al., 1985) and in the spent media of human granulosa-lutein cell cultures (Hill et al., 1987; Gitay-Goren et al., 1990; Bar-Ami and Gitay-Goren, 1993).

A low oestradiol:progesterone ratio was found to be favourable for implantation in women undergoing IVF-embryo
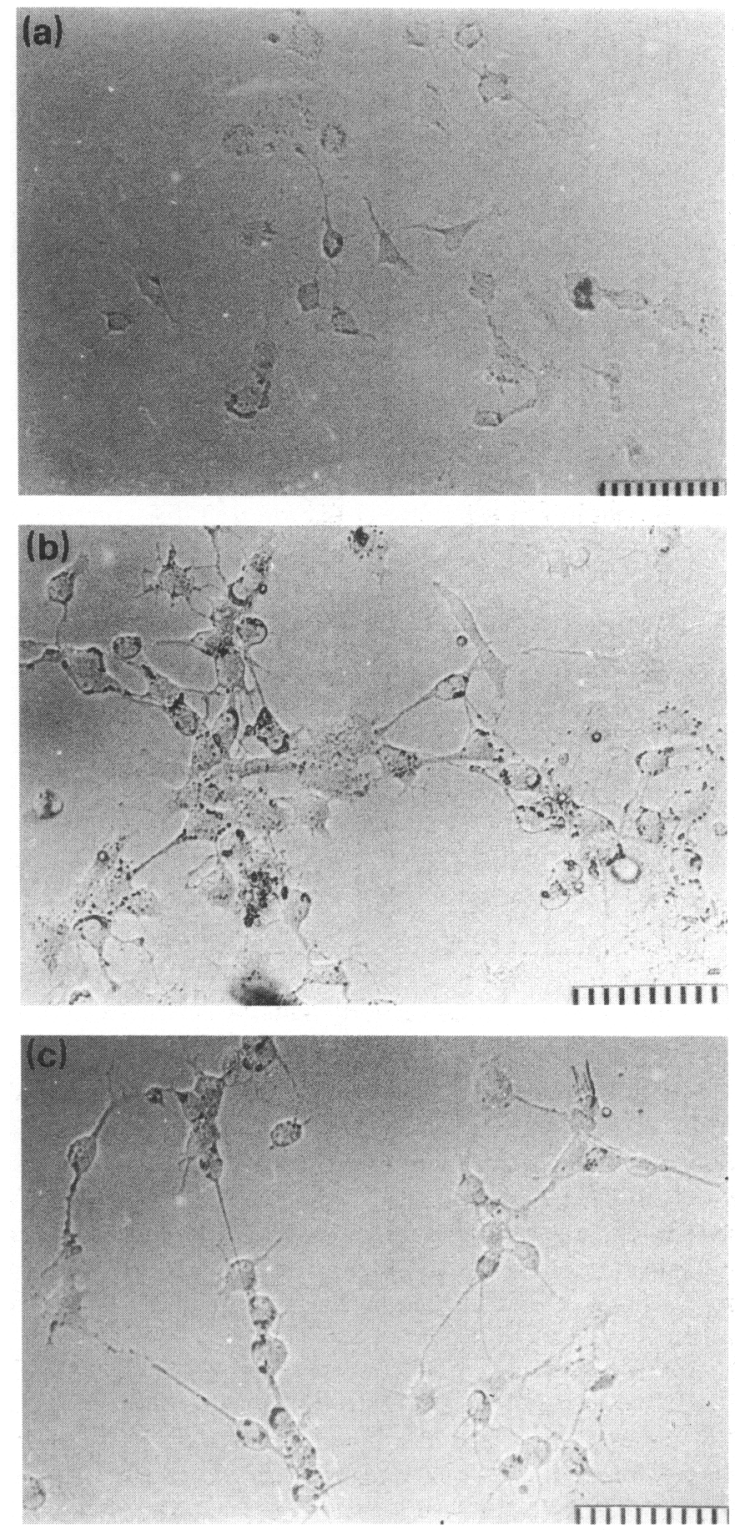

Fig. 4. Photomicrograph of human cumulus cells inoculated at $2 \times 10^{4}$ cells per dish after 3 days of culture. Cells were cultured in (a) medium alone or in medium supplemented with (b) human FSH or (c) hCG. Scale bar represents $100 \mu \mathrm{m}$.

transfer (Lejeune et al., 1986). The increase in the progesterone: oestradiol ratio that is induced by $\mathrm{LH} / \mathrm{hCG}$ might be one of the parameters that is used to evaluate degree of luteinization. A significant increase in the progesterone:oestradiol ratio has been noted in mature cumulus cell masses aspirated from women subjected to IVF-embryo transfer treatment, as well as in mature cumulus masses producing type $\mathrm{D}$ morphology in culture (Bar-Ami et al., 1989). The gradual increase in progesterone:oestradiol ratio with increase in cell-plating density during days $0-3$ and 3-5 suggests an increase in the degree of luteinization of cumulus cells with an increase in cell-plating density. In granulosa-lutein cell cultures, the progesterone:oestradiol ratio increases with increased cell-plating density and with time in culture (Bar-Ami and 
Gitay-Goren, 1993). However, in cumulus cells, there was a significant decrease in the progesterone:oestradiol ratio during days 5-7. Treatment with hFSH or hCG was necessary to prevent the decrease in the progesterone:oestradiol ratio observed during days 5-7. Although in granulosa-lutein cell cultures the progesterone:oestradiol ratio was not reduced with extension of the culture period, the addition of gonadotrophins increased the ratio at the higher cell-plating densities but decreased the ratio at low cell-plating densities (Bar-Ami and Gitay-Goren, 1993). The difference between cumulus cells and granulosa-lutein cells in relation to cell-plating densities suggests a difference in the mechanism of gonadotrophic stimulation of progesterone secretion in cumulus cells compared with granulosa-lutein cells. We conclude that, for cumulus cells to respond properly to gonadotrophin stimulation in terms of increasing progesterone and decreasing oestradiol secretion, their optimal cell-plating density is markedly lower in comparison with granulosa-lutein cells.

In cumulus cells cultured at $2 \times 10^{4}$ cells per dish, the addition of gonadotrophins induced an increase in the number of cytoplasmic processes among them. This result suggests that an increase in cell-to-cell contact participates in the stimulation of progesterone secretion by gonadotrophins in cumulus cells. However, cumulus cells at $8 \times 10^{4}$ cells per dish had more cell-to-cell contact than did cumulus cells at $0.25 \times 10^{4}$ cells per dish (which were seen mostly as single cells) and cumulus a plating density of $2 \times 10^{4}$ cells per dish. Nevertheless, cumulus cells at $8 \times 10^{4}$ cells per dish did not respond with a significant increase in progesterone secretion when exposed to $\mathrm{hFSH}$ or hCG. Only cumulus cells inoculated at $2 \times 10^{4}$ cells per dish, responded to the gonadotrophic stimulation with an increase in progesterone and a decrease in oestradiol secretion.

However, when human cumulus cells inoculated at $2 \times 10^{4}$ cells per dish were plated onto an extracellular matrix, progesterone secretion decreased by more than $50 \%$ (S. Bar-Ami and $\mathrm{C}$. Khoury, unpublished). Neither FSH nor hCG overcame this inhibition of progesterone secretion. Plating onto an extracellular matrix was associated with a marked increase in the number of cellular processes between cells. This is similar to the situation when granulosa-lutein cells were cultured on native extracellular matrix; numerous long cellular processes that were associated with increasing gap junction frequency were produced in the case of granulosa-lutein cells. However, there was a concomitant significant increase in progesterone secretion after addition of hCG (Amsterdam et al., 1989). Collectively, these data suggest that, in contrast to granulosalutein cells, cumulus cells can be diluted but should still preserve some cell contact to respond to gonadotrophic stimulation in terms of an increase in progesterone secretion.

A role for cumulus cells in the process of fertilization has been suggested by Vanderhyden and Armstrong (1989) and Tesarik et al. (1990). Furthermore, it has been shown that co-culture of cumulus-oocyte complexes with granulosa cells (Vanderhyden and Armstrong, 1990) or with hormonal supplements (Shalgi et al., 1979) can increase the incidence of fertilization and the quality of the developed embryos. The present study suggests that the use of $2 \times 10^{4}$ cumulus cells per dish provides a suitable model to investigate the role of cumulus cells in the process of fertilization and to improve the success of IVF.
The administration of exogenous hCG in vivo induces cumulus cell disconnection and an increase in hyaluronic acid accumulation in the cumulus mass. These changes coincide with an increase in progesterone secretion by cumulus cells (Laufer et al., 1984; Bar-Ami et al., 1989). The increase in cumulus volume appears to be important for uptake of the cumulusoocyte complex by the fimbria and its movement within the Fallopian tube (Blandau, 1969; Mahi-Brown and Yanagamachi, 1983). The approach taken in the present study suggests that the increase in volume of the cumulus, which results in dilution of the cumulus cells in the hyaluronic acid, is also important in enhancing the change in the cumulus cell steroidogenic pattern.

This study is submitted in partial fulfilment of the requirements for the DSc degree of C. Khoury at the Technion-Israel Institute of Technology. The authors thank D. Stein and M. Pilar for technical assistance and R. Singer for typing and editing the manuscript. This work was supported in part by the Chief Scientist's Office of the Israel Ministry of Health and by the Ben-Gurion Foundation of the Israel General Union.

\section{References}

Amsterdam A, Rotmensch S, Furman A, Venter EA and Vlodavsky I (1989) Synergistic effect of human chorionic gonadotropin and extracellular matrix on in vitro differentiation of human granulosa cells: progesterone production and gap junction formation Endocrinology 124 1956-1964

Bar-Ami S and Gitay-Groren H (199.3) Altered steroidogenic activity in human granulosa-lutein cells at different cell densities in culture Molecular and Cellular Endocrinology 90 157-164

Bar-Ami S, Gitay-Goren H and Brandes JM (1989) Different morphological and steroidogenic patterns in oocyte/cumulus-corona cell complexes aspirated at in vitro fertilization Biology of Reproduction 41 761-770

Blandau RJ (1969) Gamete transport-comparative aspects. In The Mammalian Oviduct pP 129-162 Eds ESE Hafez and RJ Blandau. University of Chicago Press, Chicago

Carson RS, Trounson AO and Findlay JK (1982) Successful fertilization of human oocyte in vitro: concentration of estradiol-17 $\beta$, progesterone, and androstenedione in the antral fluid of donor follicles Joumal of Clinical Endocrinology and Metabolism 55 798-800

Chen L, Wert SE, Hendrix EM, Russell PT, Cannon M and Larsen WJ (1990) Hyaluronic acid synthesis and gap junction endocytosis are necessary for normal expansion of the cumulus mass Molecular Reproduction and Development $26 \quad 236-247$

Cohen J, Malter HE, Talansky BE and Grifo J (1992) Micromanipulation of Human Gametes and Embryos. Raven Press, New York

DekeI $\mathrm{N}$ and Kraicer PF (1978) Induction in vitro of mucification of rat cumulus oophorus by gonadotropins and adenosine $3^{\prime}, 5^{\prime}$-monophosphate Endocrinology 102 1797-1802

Doody KJ, Lorence MC, Mason II and Simpson ER (1990) Expression of messenger ribonucleic acid species encoding steroidogenic enzymes in human follicles and corpora lutea throughout the menstrual cycle Journal of Clinical Endocrinology and Metabolism 70 1041-1045

Eppig JJ (1987) The relationship between cumulus cell-oocyte coupling, oocyte meiotic maturation, and cumulus expansion Developmental Biology 39 268-272

Gitay-Goren H, Brandes JM and Bar-Ami S (1990) Altered steroidogenic pattern of human granulosa-lutein cells in relation to cumulus cell culture morphology Journal of Steroid Biochemistry 36 457-464

Goldschmit D, Kraicer P and Orly J (1989) Periovulatory expression of cholesterol side-chain-cleavage cytochrome P-450 in cumulus cells Endocrinology 124 369-378

Hill GA, Herbert CM, Wentz AC and Osteen KG (1987) Use of individual human follicles to compare oocyte in vitro fertilization to granulosa cell in vitro luteinization Fertility and Sterility $\mathbf{4 8}$ 258-264

Johnson DC (1988) Loss of ovarian 17 $\alpha$-hydroxylase/C17,20-lyase activity induced by human chorionic gonadotrophin is correlated with in vivo substrate availability Joumal of Steroid Biochemistry $29545-551$ 
Laufer N, DeCherney AH, Haseltine EP and Behrman HR (1984) Steroid secretion by the human egg-corona-cumulus complex in culture Journal of Clinical Endocrinology and Metabolism 58 1153-1159

Lejeune B, Camus M, Deschacht J and Leroy F (1986) Differences in luteal phases after failed or successful in vitro fertilization and embryo replacement Journal of In Vitro Fertilization and Embryo Transfer 3 358-365

Mahi-Brown CA and Yanagamachi R (1983) Parameters influencing ovum pickup by oviductal fimbria in the golden hamster Gamete Research 8 1-10

Moor RM and Cran DG (1980) Intercellular coupling in mammalian oocytes. In Development in Mammals Vol. 4 pp 3-37 Ed. MH Johnson. Elsevier/NorthHolland, Amsterdam

Pereda J, Cheviakoff S and Croxatto HB (1989) Ultrastructure of a 4-cell human embryo developed in vivo Human Reproduction 4 680-688

Racowsky C and Satterlie RA (1985) Metabolic, fluorescent dye and electrical coupling between hamster oocytes and cumulus cells during meiotic maturation in vivo and in vitro Developmental Biology 108 191-202

Rodgers RJ, Waterman MR and Simpson ER (1986) Cytochrome P-450 $\mathrm{P}-45 \mathrm{O}_{17 \alpha^{\prime}}$ adrenodoxin and reduced nicotinamide-adenine dinucleotide phosphate-cytochrome P-450 reductase in bovine follicles and corpora lutea: changes in specific contents during the ovarian cycle Endocrinology 118 $1366-1374$

Salustri A, Yanagishita M and Hascall VC (1990) Mouse oocytes regulate hyaluronic acid synthesis and mucification by FSH-stimulated cumulus cells Developmental Biology 138 26-32

Sano Y, Suzuki K, Arai K, Okinaga S and Tamaoki B-I (1981) Changes in enzyme activities related to steroidogenesis in human ovaries during the menstrual cycle Journal of Clinical Endocrinology and Metabolism 52 994-1001

Sasano H, Okamoto M, Mason JI, Simpson ER, Mendelson CR, Sasano N and Silverberg SG (1989) Immunolocalization of aromatase, 17 $\alpha$-hydroxylase, and side-chain-cleavage cytochrome P-450 in the human ovary Journal of Reproduction and Fertility 85 163-169
Shalgi R, Dekel N and Kraicer PF (1979) The effect of LH on the fertilizability and developmental capacity of rat oocytes matured in vitro Joumal of Reproduction and Fertility 55 429-435

Sotelo JR and Porter KR (1959) An electron microscope study of the rat ovum Journal of Biophysical and Biochemical Cytology 5 327-341

Suzuki K and Tamaoki B-I (1983) Acute decrease by human chorionic gonadotropin of the activity of preovulatory ovarian 17a-hydroxylase and C-17-C-20 lyase is due to decrease in microsomal cytochrome P-450 through de-novo synthesis of ribonucleic acid and protein Endocrinology 113 1985-1991

Tesarik J, Testart J, Leca G and Nomé F (1990) Reversible inhibition of fertility in mice by passive immunization with anticumulus oophorus antibodies Biology of Reproduction 43 385-391

Vanderhyden BC and Armstrong DT (1989) Role of cumulus cells and serum in the in vitro maturation, fertilization, and subsequent development of rat oocytes Biology of Reproduction 90 720-728

Vanderhyden BC and Armstrong DT (1990) Effects of gonadotropins and granulosa cell secretions on the maturation and fetilization of rat oocytes in vitro Molecular Reproduction and Development 26 337-346

Vanderhyden BC, Caron PJ, Buccione R and Eppig JJ (1990) Developmental pattern of the secretion of cumulus expansion enabling factor by mouse oocytes and the role of oocytes in promoting granulosa cell differentiation Developmental Biology 140 307-317

Yovich JL, McColm SC, Yovich JM and Matson PL (1985) Early luteal serum progesterone concentrations are higher in pregnancy cycles Fertility and Sterility 44 185-189 